УДК $316: 61+316.4$

DOI https://doi.org/10.32840/2707-9147.2020.86.10

А. О. ПЕТРЕНКО-ЛИСАК кандидат соціологічних наук, доцент, доцент кафедри галузевої соціології факультету соціології Київський національний університет імені Тараса Шевченка

\title{
МІСЬКІ ІДЕНТИЧНОСТІ ЗА УМОВ ПОСТМОДЕРНОВИХ МІНЛИВОСТЕЙ
}

У статті зазначено про новітні ідентичності в постмодерному світі, який описаний як світ мінливостей та плинності. У світі постмодерну головною ареною, де розгортатимуться основні події, буде міський простір, навіть ширше - урбанізовані ландшафти. Міста постануть, власне, щзо вже можна спостерігати, значимішими просторами за державні як такі. Роль окремих міст, подій, котрі розгортатимуться на їхній території, постануть на передній план «спостереження» за реальністю і творення історії. Порядок денний визначатимуть міські ідентичності не менше, ніж політичні чи національні.

У межах поданої статті представлено авторське визначення новітніх типів міських ідентичностей, які є плинними й постають теоретичним конструктом для опису сучасних ідентичностей у містах постмодерну. Це такі типи, як урбанавт та урбаноїд. Обидва типи виникають із серії ситуативних (політичних, культурних та інших) подій чи особистих практик індивідів $і$ змінюються теж ситуативно. Пропонована теоретична модель міської ідентичності є радше інструментом для розпізнавання і структурування типів містян, розставляння акцентів і формування конщептуальної визначеності в подальших розвідках чи технологіях.

Урбанавтом ми визначаємо тип містянина, який схильний до ідеї справедливого міста, який вірить у місто рівних шансів, можливостей та прав, прагне розбудовувати спільноту мешканців, керується иінностями соціальної справедливості, рівності, толерує різноманіття та гуртовність. Урбаноїд є типом містянина, який передусім циінує місто за той перелік комфорту, який воно йому надає, за можливості й шанси отримати бажаний сервіс, послуги та иінності, не надто схильний до об' єднання з іншими містянами, втім, здатний до кооперації передусім у запиті на право захисту власних інтересів. Поєднує обидва типи прихильність до міста, як простору власного життя і свого майбуття.

Ключові слова: ідентичність, постмодерн, мінливість, урбанавт, урбаноїд.

Постановка проблеми. Ідентичність, а краще сказати у множині ідентичності сучасного світу постмодернові, як і теоретична основа їхнього аналізу. Плинність просякла буденні практики та (само)свідомість соціальних суб’єктів, що, зрештою, відобразилось не тільки у сценаріях повсякдення, але й на рівні прийняття глобальних рішень

(C) А. О. Петренко-Лисак, 2020 
і формуванні трендів майбутнього. Ідентичність, яка поціновувалась за сталість, натепер підривається дискретністю, гнучкістю, нестабільністю соціальних практик і процесів, а також невизначеністю. Вона стає множинною, ситуативною, вибірково-ймовірнісною. Ідентичність почасти стає тимчасовим, відносним, незавершеним конструктом, який отримує онтологічний статус проєкту чи тимчасового/ситуативного теоретичного постулату. В точковому часі плинної модерності (який саме таким визначив 3. Бауман [2]) соціальні трансформації набувають фрагментарності, творять мозаїчний фрейм соціальної реальності. Від цього ідентичність соціальних суб'єктів не встигаючи оформитись, вже відчуває утиск бути знову трансформованою.

Проблема ідентичності в соціології досліджується досить широко: від особистісного масштабу до інституційного, від локального до глобального, від конкретно інституційного до системного. Саме поняття ідентичності фактично не потребує уточнення. Втім, здавалося б, стале розуміння ії̈ як встановленої тотожності, відповідності до речей і процесів, - про ідентичність виявилось складно однозначно зазначити як про знане явище в теорії постмодернової часовості. 3. Бауман говорив про змінну ідентичність, коли проблема тожсамості, власне ідентичності, позбулась сталого поняття. Кожна людина протягом життя «приміряє маски», шукаючи зручну до часу і простору чи вигідну до обставин подібність. І в цьому - iї плинність.

Аналіз останніх досліджень і публікацій. В умовах постмодерного суспільства 3 його багатомірністю топологічної диференціації (П. Бурдьє) ідентичності конструюються у взаємодії різноманітних, часом суперечливих дискурсів, практик і позицій у межах дискурсивних формацій, які лише назагал визначають, «що може й повинно бути сказане» (М. Фуко). Такі конструкти неминуче мультипліцитні, фрагментарні, постійно перебувають у процесі змін і трансформацій.

М. Кастельс розуміє під ідентичністю процес, через який соціальний актор упізнає себе й конструює смисли, головно на основі певної культурної властивості або сукупності властивостей, окрім ширшої співвіднесеності з іншими соціальними структурами. Він пропонує поглянути на ідентифікацію як на самобутність у постіндустріальному суспільстві, виділяючи три типи ідентичності: «легітимізуючу»породжену індустріальним суспільством із його традиційним розумінням громадянського суспільства й національної держави; ідентичність «спротиву» - пов'язану з переходом до нового типу цінностей, котрі створюються локальними спільнотами; та «проєктивну» ідентичність, яка визначається формуванням особистості, самого суб'єкта [4]. На думку М. Кастельса, «ідентичність спротиву» проявляється в нових соціальних рухах (жіночому, екологічному). Базовий принцип такого типу рухів - контроль за часом та постановка технологій на службу індивідам. Подібні рухи використовують технологію для горизонтальної комунікації між людьми, пропагування цінностей спільноти, дола- 
ючи тотально об’єктивоване існування індивіда, спровоковане натиском технологій.

Окрім зазначених авторів, міркуваннями щодо ідентичностей в епоху постмодерну варто зазначити, зокрема, Р. Сеннета, Р. Флориду, Ж. Атталі, У. Бека, Дж. Уррі, Е. Тофлера, а також П. Гілена.

Мета статті. Головною метою цієї роботи є визначення новітніх типів міських ідентичностей, які є плинними й постають теоретичним конструктом для опису сучасних ідентичностей у містах постмодерну.

Виклад основного матеріалу. Ідентичність має дві сторони прояву: статичну та динамічну, відповідно, здатна демонструвати зміни та трансформації. Нестійкість ідентичності, на нашу думку, проявляється тим, що вона, по суті бувши продуктом складних взаємодій культури, історії, множини результатів впливу факторів і процесів, - ще є наслідком свідомих доцільних впливів та управління зі сторони соціальних суб'єктів. «Управління щодо ідентичностей означає, що вони можуть досить свідомо, цілеспрямовано проєктуватись, конструюватися, деконструюватись, форматуватись, переформатовуватись - інакше кажучи, змінюватись. У різні епохи таке управління переслідувало різні цілі. Сьогодні політика формування ідентичності використовується (державою, церквою, елітою, ЗМІ, соціальними суб'єктами тощо) переважно як інструмент вибудови поля соціальної комунікації між носіями різних культур, релігій, цінностей, ідей, уподобань тощо, хоча не виключаються й інші цілі - наприклад, ствердження однієї ідентичності на шкоду іншої, аж до усунення носіїв останньої» [3]. Користуючись мінливістю світу, соціальні технології здатні штучно виробити підгрунтя, на якому формуватиметься чи наполегливо пропонуватиметься та чи інша запроєктована ідентичність. Невизначеність соціальних перспектив, політичні конфлікти, економічні негаразди, релігійні суперечки та суперечності, відсталість і невідповідність новітнім трендам в освітніх практиках здатні бути використаними як обгрунтування пропонованим форматам самовизначення.

Водночас варто зазначити, що плинна сучасність демонструє й радикальну індивідуалізацію. Індивіди звільняються від фреймів загальної культури визначених державою проєктів гомогенізації. Плинна сучасність живе в умовах посткультури, де вона більше не означає культивування певних визначених цінностей, проте $є$ ринком культурного плюралізму, де «виграє» той, хто краще себе п(р)одав.

Ідентичність, не бувши стабільним осердям самості, а навпаки, такою, що артикулює неможливість інтегральної, гармонійної, заданої на всі часи моделі, - відтак трансформується в таких межах, як ареал поширення, вернакулярність простору, темпоральна визначеність форм прояву та атрибутації.

Постмодернова ідентичність виникає із серії ситуативних (політичних, культурних та інших) подій і змінюється теж ситуативно. Маркери ідентичності рухливі, вони зумовлюються безліччю чинників: геогра- 
фією культурних ареалів, історичними кордонами соціополітичних утворень, маргіналізацією або націоналізацією суспільства, трансформаціями в будь-якому елементі соціокультурної системи тощо.

Така ідентичність $є$ своєрідним інструментом для розпізнавання i структурування реальності в часі і просторі, розставляння в ній акцентів і формування визначеності. Причому йдеться про визначеність швидше процедурну, ніж змістовну, визначеність маркування, називання людей, речей і відносин легалізованим чи узгодженим ім'ям.

У суспільстві мережевих структур складається далеко не гармонічна структура, оскільки логіка груп із відмінною ідентичністю $є$ взаємозаперечною, а їхнє існування - далеко не мирне. Еліту в суспільстві мережевих структур, як правило, формують «громадяни світу», котрі володіють «найневиразнішою самобутністю». Одночасно 3 ними співіснують індивіди, які пручаються втраті своїх привілеїв у різних сферах суспільства й тяжіють до визначеної самобутності від суспільства.

Нестабільний стан індивіда - мабуть, перша причина того, що він трансформує власну самооцінку. Причому не факт, що зміна зовнішніх обставин змінюватиме самооцінку індивіда. Він здатен уперто дотримуватись обраної самості, як своєрідного якоря. Проте в умовах постійних і досить швидкоплинних суспільних і соціальних трансформацій індивід, спостерігаючи й відчуваючи темп змін, перебуває в потоці рішень: бути тим, ким він себе має чи прагнути змінити ставлення й оцінку себе, щоб пристосуватись до мінливого середовища.

Міркуючи над ідентичностями сучасного урбанізованого світу, над змінами, яких зазнає соціальний простір у поступі інформаційно-комунікативних технологій, які нерідко диктують форми відносин та взаємодій, - ми звернули увагу на трансформації міської ідентичності. К. Шульман зазначає, що місто «передбачає скупченість великої кількості людей на обмеженому просторі, на якому вони змушені домовлятись один з одним. Містяни приречені на $<\ldots>$ відстоювання своїх інтересів та досягнення компромісів з іншими. Всі в місті ходять одними й тими самими вулицями, їздять на одному громадському транспорті чи на машинах одними й тими ж дорогами, й водночас це люди надзвичайно відмінні один від одного: з різним достатком, різними заняттями і вподобаннями, різним рівнем освіти, різною кваліфікацією й різним режимом дня. Людина, яка живе в місті, вчиться двом речам: взаємодії та толерантності» [5, с. 33].

Блогер Ілля Бейлін наївно й публіцистично озвучив метафори двох образів міських мешканців - «урбаноїда» та «урбанавта». Нас вони зацікавили і внаслідок міркувань над ними постала розроблена нами дуальна теоретична типологія міської ідентичності. Це уявлювані полярні образні категорії містян. Але ідея має потенціал для розробки емпіричних критеріїв. Поки що варто розібратись із їі евристичними характеристиками. 
В основу словотворення та семантики даних типів покладено мовну етимологію. Суфікс «-НАВТ» походить від грец. Naus - «корабель, судно»; «мореплавець, матрос» і надає значення відповідної основи. Таким чином, особа типу «урбанавт» нібито містоплавець, «міська Одісея» якого - це життєві мандри людини, яка виходить у простір міста в пошуках самої себе. Урбанавт позбавляється свого Его та водночас знаходить його, в цьому його втіха. Він почасти як пілігрим, який знає свої сили, проте в якісь моменти сумнівається в них.

Суфікс «-ОЇД» походить від грец. Eidos - «вид, образ», надає значення уподібнення, вказує на особу чи предмет, який подібний тому, що визначає базова основа. Тому «урбаноїд» - це суб' єкт місту(о) подібний. Урбаноїд відправляється до тернів міста в пошуках чужого «Я», адже свого «Я» в нього немає, але не в тому сенсі, що він не виокремлює себе як особистість, а хіба в тому, що він не надто опікується проблемою власного самовизначення. Иому важливо зрозуміти, не хто він сам, але хто його оточує, чи здатен він серед інших знайти схожих на себе, щоб перебувати в умовах комфортного оточення. Він мисливець. Урбаноїд не шукає своє Его, але слухняно за ним іде; вважає, що знає свої сили.

В урбанавта немає бажання ранжувати, узагальнювати, він намагається описати складки міста, в яких немає місця політичним і культурним маніпуляціям. Тільки творчість. Урбанавт по-своєму любить місто, знаходячи принадність у його різноманітних дослідженнях, у самих процесах рецепцій. Іноді урбанавт - міський сталкер - шукач щастя і живих душ у містах.

Урбаноїд - це житель міста, в якому паливо й фастфуд або гастровишуки - необхідний атрибут та натуральний антураж. Не варто вважати урбаноїда оспівувачем міста в його унікальності. А проте саме урбаноїд є кращим провідником міськими лабіринтами, ніж урбанавт. Урбаноїд живе в системі автоматичного керування, інстинктивно діє у вирах міста. Для нього місто - це даність, звабливий простір, але не той, що кортить прискіпливо й філософськи досліджувати; всі свої «урбаністичні молитви та ритуали» він здійснить у годину пік, повертаючись додому через гіпермаркет на автотранспорті, переважно власному (поки немає такого, він страждає у громадському). Урбаноїд споживач міста, він не схильний до глибоких рефлексій, на відміну від урбанавта.

Урбанавт ідеалізує місто, він прагне бачити його ідеал у форматі гемайншафту - спільноти із сильними зв'язками - тісними, особистісно визначеними зв'язками й ролями; він прихильник спільнот i всіма способами прагне їх розбудовувати, зокрема, користуючись методами партисипативності; для урбанавта - трагедія бути однаком, самотнім; самотність не вважає свободою, свобода - це вічний пошук.

Урбаноїд користується містом як лабораторією, не прагнучи об'єднуватись у громади; цілком комфортно він почувається у форматі 
гезельшафту - суспільства, де переважають слабкі зв'язки, котрі не потребують постійних контактів зі співмешканцями, де тимчасові, функціональні відносини; урбаноїд - прихильник індивідуалізму; урбаноїд - одинак, у самотності він бачить певне вираження свободи.

Урбанавт мультикультурний, він прагне знайти баланс, займаючи доброзвичайну терпимість до культур, котрі виключають будь яку симетричну терпимість.

Урбаноїд може бути толерантним, - готовим змиритись із певними речами, які активно не подобаються, проте в межах певних границь та до певних меж.

Способом домовитись для урбанавта $є$ дискусія, обговорення, щораз пошук усередненого рішення. Спосіб домовитись, узгодитись для урбаноїда - це дотримуватись усіма містянами однаково закону і правил за мовчазної спільної згоди.

Урбанавт - політичний - він прихильник колективних рішень у місті. Натомість урбаноїд - аполітичний - (у давньогрецькому сенсі «ідіотичний») він приватний i замкнений. Його будинок має бути огороджений від чужинців, зівак-туристів, пияк та безпритульних.

Життя урбанавта - фланерське. Місто вабить його відчуття та почуття. Урбаноїд - споживач міста. Його рольова позиція в рубці креативного класу - це роль гурмана, який вимагає індивідуалізованого обслуговування, комфорту, задоволення його особливих унікальних смаків. Тоді як позиція урбанавта - це роль провідника, проповідника, який прагне досить наполегливо впровадити власну віру, цінності, залучити до них оточення, легкий на підйом до зміни норм і традиційних правил.

Урбанавтом домінує стиль міського життя, урбаноїдом - спосіб міського життя.

«Право на місто» урбанавта - новоурбаністичне, іноді його світоглядна модель - романтично-консервативний урбанізм. «Право на місто» урбаноїда - нормативне право на послуги й сервіс від інфраструктури міст. Урбанавт на борту свого корабля написав би: «Let's go! Will be fan!», тоді як урбаноїд не написав би нічого, промовивши «Тільки не на моєму кораблі!».

Застосовуючи своє повне право на місто, вони реально здатні співтворити та змінювати космічний уклад міста, з усією його логікою й парадоксами. Суперечність тут є: іманентна логіка природи типів виштовхує урбанавта на цінності гезельшафту (права городян на місто у форматі Полісу вільних громадян), але він вибудовує свій ідеал міста на гемайншафт ідеалах, й відповідно, урбаноїд, здавалося б, мав прагнути гемайншафту (проживання у вузькій спільноті подібних), але він поціновує гезельшафт умови. Внутрішня боротьба постає як вічний двигун цього Всесвіту міського життя.

Е. Глейзер, прагнучи узгодити полярні міські ідентичності, зауважує: «Але як окремі міста можуть стати споживацькими містами та прива- 
бити кваліфікованих мешканців? Одна позиція, яка поділяється Ричардом Флоридою, підкреслює значення мистецтв, толерантності до альтернативних стилів життя, а також необхідність наявності жвавого центру міста із множиною веселих заходів. Друга позиція фокусується на тому, що необхідно підвищувати якість базових суспільних послуг, які завжди були в розпорядженні міст, - безпечних вулиць, швидкого транспорту, хороших шкіл. У керівників міста зазвичай обмежені ресурси, вони не можуть задовільнити бажання кожного. Навіть якщо поділяти мою думку і вважати, що кожне місто має певною мірою підтримувати обидві ці концепції, завжди буде стояти питання, куди інвестувати доходи міського уряду та енергію його керівників» [1, с. 387].

Людина у ставленні до міста проходить шлях переходів між зазначеними нами двома ідентичностями: урбаноїдною та урбанавтною. В окремих ситуаціях вона обирає для себе стратегію своєї поведінки, яка відповідає чи тій, чи іншій моделі ідентичності. Домінантою переходів $є$ іi поточний соціальний статус та процес життєдіяльності, котрі визначають їі стиль чи спосіб життя. Чи можлива усталена стабільна модель усвідомлення себе в місті? Так, у разі, коли індивід проживає все життя в одному місті й, одного разу зупинившись на зручній ідентичності, надалі вже не змінює іiі, демонструючи своєю поведінкою та висловлюючи в оцінках належність саме до неї протягом тривалого часу. Проте, як стверджується дослідниками ідентичності, її незмінної форми фактично не буває. Різниться лише час, за який вона себе виявляє. Процес соціалізації - мінливий, хоч i має визначену поетапність. Проте зміни, які його супроводжують, $\epsilon$ нестабільними й залежать від політичних, культурних, економічних та інших суспільних факторів.

Висновки і пропозиції. Отже, ідентичність сучасного світу постмодернова, як і теоретична основа ii аналізу. Плинність, яку помітили і про яку міркували 3. Бауман, М. Кастельс, Дж. Уррі, Р. Сеннет, П. Гілен та низка інших менш відомих теоретиків і аналітиків, насправді просякла буденні практики та (само)свідомість соціальних суб'єктів, що, зрештою, відобразилось не тільки в портретах повсякдення, але й на рівні прийняття глобальних рішень і формування трендів майбутнього. Ідентичність, яка поціновувалась за сталість, натепер підривається дискретністю, гнучкістю, нестабільністю соціальних практик і процесів. Постає затребуваним пошук нових означень та понять, котрі описуватимуть сучасні тренди. У світі постмодерну, де міста відіграють чи не ключову роль як простори формування майбутнього, постають дві стратегії: життя та виживання. Міська ідентичність стала мінливою та ситуативною. В точковому часі соціальні трансформації набувають фрагментарності, творять мозаїчний фрейм соціальної реальності. Від цього ідентичність соціальних суб'єктів, невстигаючи оформитись, уже відчуває утиск бути знову трансформованою. 


\section{Список використаної літератури}

1. Глейзер Э. Триумф города. Как наше величайшее изобретение делает нас богаче, умнее, экологичнее, здоровее и счастливее / пер. с англ. И. Кушнаревой. Москва : Изд-во Института Гайдара, 2014. 432 с.

2. Ми рухаємося в еру точкового часу, - Бауман. ZAXID.NET. 10 вересня, 2013 p. URL: https://zaxid.net/mi_ruhayemosya_v_eru_tochkovogo_chasu_bauman_ n1293124.

3. Митрошенков О.А. Идентичность: от теоретического концепта к управленческим воздействиям (социально-философский анализ). Власть. 2006. № 2. C. 14-28. URL: https://cyberleninka.ru/article/n/identichnost-ot-teoreticheskogo-kontsepta-k-upravlencheskim-vozdeystviyam-sotsialno-filosofskiy-analiz.

4. Кастельс М. Информационная эпоха: экономика, общество и культура: Пер. с англ. под научн. ред. О.И. Шкаратана. Москва : ГУ-ВШЭ, 2000. 608 с. URL: https://www.gumer.info/bibliotek_Buks/Polit/kastel/index.php.

5. Шульман Е. Придется договариваться. Почему у горожанина будущего будут спрашивать про все. Горожанин: что мы знаем о жителе большого города? Москва : Strelka Press, 2017. С. 30-47.

Petrenko-Lysak A. O. Urban identities in the context of postmodern fluidity

This article is about the newest identities in postmodern world. It is a variability and fluidity world. In postmodern world the urban space will be the main arena where the main occasions will take place. Even wider - urban landscapes. Cities will be spaces that are more important than state ones. This can already be observed.

The role of individual cities, the events that will happen on their territory will come to the fore "observation" of reality and the making of history. The agenda will be defined by urban identities no less than political or national ones.

This article presents the author's definition of the newest types of urban identities. They are fluid and serve as a theoretical construct to describe modern identities in postmodern cities.

These are such types as urbanaut and urbanoid. Both types arise from a series of situational (political, cultural and other) events or personal practices and also change situationally.

The proposed theoretical model of urban identity is rather a tool for recognizing and structuring types of citizens, placing emphasis and forming conceptual certainty in further researches or technologies.

We define urbanist as the type of citizen who is inclined to the idea of a justice city, believes in a city of equal chances, opportunities and rights, seeks to build a community of residents, guided by the values of social justice, equality, tolerance of diversity and community.

Urbanoid is a type of a citizen who primarily values the city for the list of comfort it provides him, for the opportunities and chances to get the desired maintenances, services and values.

It is not very up to unite with other citizens, but is able to cooperate primarily in the request for the own interests 'protection right.

Both types have the idea of commitment to the city as a space of their own lives and their future in common.

Key words: identities, postmodern, fluidity, urbanaut, urbanoid. 